\title{
BDNF gene polymorphysm RS2049046 in episodic and chronic migraine
}

\author{
Y Azimova*, A Sergeev, K Skorobogatykh \\ From The European Headache and Migraine Trust International Congress \\ London, UK. 20-23 September 2012
}

\section{Background}

The brain-derived neurotrophic factor (BDNF) is closely involved in the pathophysiology of mood disorders and pain processing. An increased risk for the AT-genotype of rs2049046 in BDNF gene and the GC-genotype of rs1553005 in CGRP gene was previously reported in migraine patients.

\section{Aim}

The aim of the study was to investigate the prevalence of BDNF gene polymorphism rs2049046 in chronic and episodic migraine.

\section{Patients and methods}

117 patients with migraine (ICHD II), 12 men and 105 women, mean age $40.7 \pm 12.1$ y.o. were included. 78 patients had episodic migraine (EM) and 39 had chronic migraine (CM). SNP rs2049046 was genotyped by PCR-RLFP technique: PCR with "GenPakTM PCR Core" (Isogene Laboratory, Ltd) and restriction with Hinfl (SibEnzyme Ltd).

\section{Results}

The prevalence of TT genotype of rs2049046 was significantly higher in CM group (20.5\%) compared with EM group (6.4\%), $\mathrm{p}=0.022$. The prevalence of AA ( $8.9 \%$ in EM group and $7.7 \%$ in CM group) and AT genotypes (84.6\% in EM group and $71.8 \%$ in CM group) did not differ significantly.

\section{Conclusions}

TT genotype of rs2049046 in BDNF gene appears to influence susceptibility to migraine chronification. This polymorphism could also be a link for comorbidity of chronic migraine and mood disorders.

1st Moscow State Medical University, Russian Federation
Published: 21 February 2013

\section{Reference}

1. Lemos C, Mendonca D, Pereira-Monteiro J, et al: BDNF and CGRP interactions: ipmlications in migraine suscitability. Cephalalgia 2010, 30:1375-1382.

doi:10.1186/1129-2377-14-S1-P16

Cite this article as: Azimova et al.: BDNF gene polymorphysm RS2049046 in episodic and chronic migraine. The Journal of Headache and Pain 2013 14(Suppl 1):P16.
Submit your manuscript to a SpringerOpen ${ }^{\circ}$ journal and benefit from:

- Convenient online submission

- Rigorous peer review

- Immediate publication on acceptance

- Open access: articles freely available online

- High visibility within the field

- Retaining the copyright to your article

Submit your next manuscript at $\boldsymbol{s p r i n g e r o p e n . c o m ~}$ 